\title{
Study on the Microstructural Characteristics of Some Metallic Layers Produced Using the Electrochemical Method and Thermal Spraying
}

\author{
ROXANA ALEXANDRA GHETA ${ }^{1}$, IONELIA VOICULESCU ${ }^{1 *}$, ION MIHAI VASILE ${ }^{1}$, \\ GEORGIANA CHISIU ${ }^{2}$ \\ ${ }^{1}$ Politehnica University of Bucharest, Department of Quality Engineering and Industrial Technologies, 313 Splaiul \\ Independentei, 060042, Bucharest, Romania \\ ${ }^{2}$ Politehnica University of Bucharest, department of Machine Elements and Tribology, 313 Splaiul Independentei, 060042, \\ Bucharest, Romania
}

\begin{abstract}
The paper presents the comparative analysis of the microstructural particularities and the superficial characteristics (microhardness and wear resistance) of 3 methods of producing composite layers on metallic support. The aim of the research was to study the possibility of replacing the hard chromium plating process by the thermal metallization process, in order to produce layers resistant to wear and corrosion. Samples produced by hard chromium plating (layers deposited by electrolysis), samples loaded by thermal metallization with electric arc and G3Sil wire, and samples loaded by thermal metallization with oxy-gas flame and detonation (HVOF) using tungsten carbide as filler material were used in this study.Hard chromium plating allows for high wear resistance thin layers to be produced, but the process is cumbersome and polluting. Thermal metallization allows the production of composite layers, of a chemical composition selected according to the operational demands, in much shorter times and at lower costs. In order to ensure a higher adhesion and to reduce the mechanical stresses at the support-hard layer interface, an intermediate layer of nickel was deposited in the case of samples loaded by thermal metallization with wire. In the paper, the microstructures in cross-section were analysed, the chemical compositions were determined on micro-zones related to the diffusion from the support material and the microhardness in the deposited metal and in the thermally affected zones was measured. These studies have shown that composite metallic layers displaying satisfactory mechanical and microstructural characteristics can be produced using alternative methods (thermal metallization) if optimum regime parameters are chosen.
\end{abstract}

Keywords: thermal spraying, hard chromium plating, microstructure, chemical composition, microhardness

\section{Introduction}

Many industrial applications require the use of high wear and corrosion resistance active surfaces. These surfaces can be produced for both new and reconditioned parts. The area of use of hard chromium plating reconditioning comprises a wide range of parts, including hydraulic subassemblies, engine components, pressure cylinders, etc., whose surfaces are subjected to corrosion and heavy mechanical wear. A chromium layer, of a hardness of at least $1000 \mathrm{HV}$, is applied on the surface of the parts to protect them against such stresses. Durability and reliability characteristics adapted to the requirements of the beneficiaries can be achieved by varying the thickness of the chromium layer.

The main criteria for choosing alternative processes are: ensuring the prescribed surface mechanical characteristics, good machining by cutting to obtain the desired dimensions, mechanical and chemical

*email:ioneliav@yahoo.co.uk 
stability of the layers under different operating conditions and the possibility of restoring them when wear phenomena occur. In the case of hydraulic cylinders, which are extensively used in a wide variety of industrial areas (such as civil, automotive or shipbuilding), the contact surfaces must be smooth (roughness of 1-2 $\mu \mathrm{m}$ ) and very hard $(>1000 \mathrm{HV}$ ), so as to ensure the tolerances required for proper sealing and the longest possible service life. Piston rods are usually chromed, but other alternative methods are currently being researched, as hexavalent chromium oxide is produced during the hard chromium plating process, which is a well-known carcinogen by-product.

Thermal spray coating could be considered as an alternative technique for producing complex metallic layers, similar to those produced by hard chromium plating [1]. Metallic layers produced by thermal spraying can withstand various stresses, under aggressive environmental conditions, such as abrasive wear and corrosion [2]. Some surfaces produced by thermal spraying can have better properties than the layers produced by hard chromium plating, and the former process is much more productive. Moreover, laser and powder loading is increasingly becoming a variant used for high precision industrial applications for loading with metallic-ceramic or composite layers [3-4]. The use of high-performance filler materials, such as high entropy alloys [5] or the optimization of the technological parameters of the processing, also allows achieving very good results when depositing complex layers [6-8].

The research carried out in the paper was aimed at achieving improved surface mechanical characteristics by applying the thermal spraying deposition methods, comparable to those achieved by hard chromium plating. The paper analyses two processes for thermal spray coating for obtaining of metallic layers, namely the deposition by $\mathrm{HVOF}$ thermal spraying using tungsten carbide (WC/CoCr 86/10-4) and electric arc thermal spraying using two wires as electrode (Fe-based alloy wire G3Si1) and $\mathrm{Ni}$ intermediate layer. The loaded parts were then subjected to destructive tests, i.e. cross-sectioning for microstructure and microhardness analyses, as well as local chemical composition analyses on the interface zones between the deposits and the support material.

\section{Thermal spray coating methods}

Thermal spray coating methods are mainly distinguished by the their performance, i.e. the porosity of the layers (about 10\% for electric arc metallization, 10-15\% for flame metallization, 2-5\% for plasma metallization and $1-2 \%$ for flame and HVOF detonation metallization), the maximum temperature reached in the melting zone of the filler material (between $3000-4000^{\circ} \mathrm{C}$ for electric arc or flame processes and $15000^{\circ} \mathrm{C}$ for plasma processing), the projection rate of the molten particles (between 40 and $200 \mathrm{~m} / \mathrm{s}$ for classical processes and up to $800-2500 \mathrm{~m} / \mathrm{s}$ for plasma or HVOF processes), respectively the peeling resistance of the deposited layer (10-15 MPa for flame or electric arc processes, over $50 \mathrm{MPa}$ for plasma metallization and over $70 \mathrm{MPa}$ for the HVOF process).

Most thermal spray coating processes are carried out at ambient temperature and pressure, with the exception of plasma metallization, which requires plasma generating gases (argon, nitrogen or helium) supplied at high pressure (over $5 \mathrm{~m}^{3} \mathrm{~min}^{-1}$ ) [9]. The filler material can be supplied as powder, metal bars, wire or metal melt, the final version being chosen depending on the performance of the process (the maximum temperature, the particle projection rate) and the design requirements (thickness of the layer, adhesion). The main issues that arise in the thermal metallization are: the metallized layer lacks homogeneity and is produced by the mechanical adhesion of the molten metal droplets between them and upon reaching the substrate; the microstructure of the metallized layer includes oxide films and pores $[10,11]$ as a result of the rapid cooling upon impact with the cold substrate, the metallization deposits have unique crystalline microstructures that are not usually formed in conventional metallic alloys. The disadvantages of the wire metallization process include the following effects: overheating and oxidation of the materials sprayed on a metallic substrate, unevenness of the thickness of the deposited layer. The main advantage of the electric arc spraying method is the high productivity of the process and the possibility of depositing performance materials. Thus, at high current intensity, for example $750 \mathrm{~A}$, the productivity for alloyed steel is $36 \mathrm{Kg} / \mathrm{h}$, exceeding by several times the productivity of oxy-gas flame 
spraying, and layers with significantly higher adhesion can be produced on various types of substrates. Pseudo-alloys can be produced when wires made of differing metals are used [2].

Plasma metallization is a process widely applied due to the special quality of the deposits, made with both wire and powder. The main disadvantages are the high price of the plant and the processing costs incurred with the use of plasma generating gases. The plasma torches allow the use of gas mixtures such as: Ar, Ar- $\mathrm{H}_{2}, \mathrm{Ar}-\mathrm{He}$, Ar-He- $\mathrm{H}_{2}, \mathrm{~N}_{2}$ and $\mathrm{N}_{2}-\mathrm{H}_{2}$. Most plasma torches are provided with a cathode, supplied with power ranging between 30 and $90 \mathrm{~kW}$ and powder feeding rate between 3 and $6 \mathrm{~kg} / \mathrm{h}$ at a deposition efficiency of around $50 \%$ [9].

The flame spraying method allows composite, metallic or metallic-ceramic deposits to be produced. The large amount of heat emitted by the flame and the resulting gases can lead to a significant combustion of the alloying elements in the filler material. Thus, the carbon concentration in the layers formed by spraying is by $40-60 \%$ lower than that of the original material and by $10-15 \%$ lower than that of silica and manganese. The main advantage of the method is the high flexibility and low cost of applying the process. Unfortunately, the quality of the deposited layer is often inferior compared to other metallization techniques (at a layer thickness above $6 \mathrm{~mm}$ the flaking effect may occur, Figure 1) [10, $11]$.

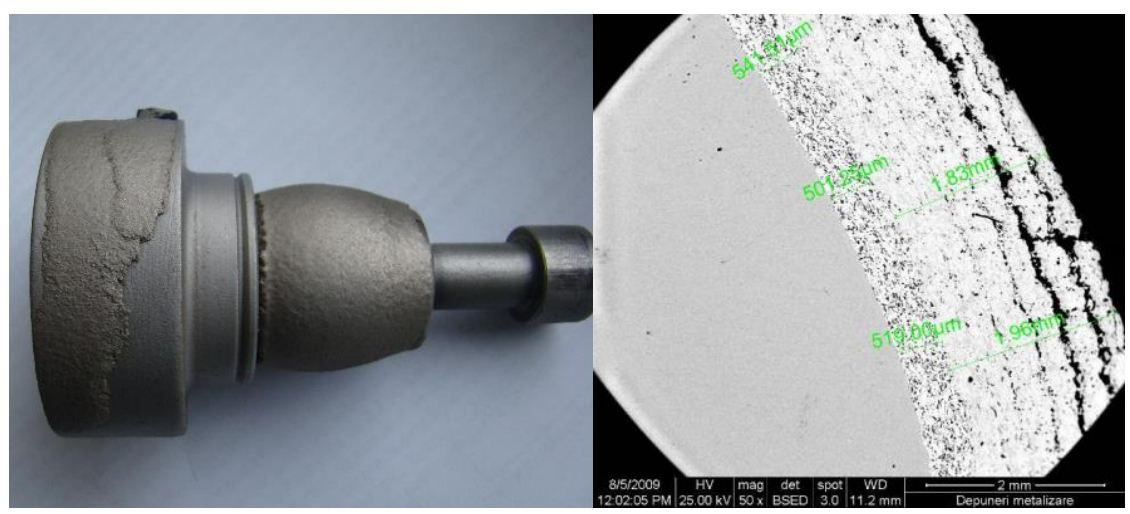

a) b)

Figure 1. Unsatisfactory appearance of a flame metallization deposit: a) peeling off the substrate; b) flaking

The HVOF (High Velocity Oxy-fuel Flame), HVAF (High Velocity Air-fuel Flame) and D-gun (Detonation gun) procedures were developed to improve the performance of flame metallization deposits. In the case of these processes, the deposited layers are very finely structured and extremely dense, using metallic or metallic-ceramic powders at very high sputtering rates and high carrier gas pressure. The rapid combustion of hydrocarbon molecules or of liquefied gases (kerosene) is produced by mixing with oxygen which reaches high pressures in the combustion chamber $(0.24$ and $0.82 \mathrm{MPa})$. In order to obtain high rates of projection of the molten particles (up to $2000 \mathrm{~m} / \mathrm{s}$ ), the system is provided with a Laval-type convergent-divergent nozzle, the power level ranging between 100 and $120 \mathrm{~kW}$, with a deposition efficiency of about $70 \%$ for powder flow rates up to $7.2 \mathrm{~kg} / \mathrm{h}$ for gas-fuel guns [9]. Although the performance of the deposits yielded by these processes is extremely good, it does not apply to substrates of low strength or high brittleness, as the shock produced upon hitting the support can cause overheating, deformation or cracks $[12,13]$. The choice of filler materials for producing composite layers greatly influences the corrosion resistance characteristics [14]. Some new metal alloys, called high entropy alloys, tend to replace conventional alloys used in special applications, due to their special mechanical and microstructural characteristics [15]. Moreover, welding deposition processes can be applied to achieve heterogeneous layers of superior mechanical strength characteristics [16, 17]. At the same time, the development of new methods for depositing nanostructured layers allows to reduce their thickness and improve the technological performance [18-24]. 


\section{Materials and methods}

\section{Hard chromium plating process}

In order to produce layers deposited electrochemically by hard chromium plating, the following steps were carried out: mechanical processing of the surfaces of the part made of $\mathrm{Cr}$ low alloy steel; cleaning the processed surfaces (degreasing and washing in an ultrasonic tank for $10 \mathrm{~min}$ ) followed by hot air drying; the chromium plating itself in the electrochemical tank; surface washing with hot water and final hard chromium plating processing.

The mechanical processing was first performed by grinding, in order to achieve the lowest roughness possible, specific to the hard chromium plating process, i.e. $\mathrm{Ra}=3 \mu \mathrm{m}$. It was followed by sanding with abrasive paper (360 - 1500 grit) and polishing with fine abrasive paste (chromium oxide), to eliminate the scratches left by the mechanical processing. In order to keep the parts at the required distance from the chromium anodes, the parts were mounted in special supports during the electrochemical deposition process. The surfaces were cleaned by chemical degreasing in aqueous solution of $70 \mathrm{~g} / \mathrm{L} \mathrm{NaOH}$ and 30 $\mathrm{g} / \mathrm{L} \mathrm{Na}, \mathrm{CO}$, at $80^{\circ} \mathrm{C}$, and electrochemical degreasing in aqueous solution of $100 \mathrm{~g} / \mathrm{L} \mathrm{NaOH}$ and $3 \mathrm{~g} / \mathrm{L}$ soluble glass $\left(\mathrm{NaSiO}_{3}\right)$. The current density for degreasing was set at $7 \mathrm{~A} / \mathrm{dm}^{2}$ and the temperature of the bath was of approximately $85^{\circ} \mathrm{C}$. After degreasing, the parts were washed with hot water to remove any trace of electrolyte that may affect the quality of the chromium deposition. The anodic etching was performed in the chromium bath, using an electrolyte made of $150 \mathrm{~g} / \mathrm{L} \mathrm{CrO}$ and $1.5 \mathrm{~g} / \mathrm{LH}_{2} \mathrm{SO}_{4}$. The solution for the actual chromium was made as follows: $200 \mathrm{~g} / \mathrm{L}$ electrolyte in the form of $\mathrm{CrO}_{3}$ powder, $35 \mathrm{~mL}$ for $1 \mathrm{~kg}$ of $\mathrm{CrO}_{3}$ additional additives of catalytic chromium, $4 \mathrm{~g} / \mathrm{L}$ ultrapure sulfuric acid, 20 $\mathrm{mL} / \mathrm{L}$ of solution chromium of HN25 catalytic purity. The parameters of the chromium plating regime were set as follows: current density, $\mathrm{Dc}=40 \mathrm{~A} / \mathrm{dm}^{2}$, solution temperature, $\mathrm{T}=60-80{ }^{\circ} \mathrm{C}$ and $10 \mathrm{~min}$ loading time.

\section{Two-wire thermal spraying process}

In order to produce the specimens loaded by thermal spraying, a $12 \mathrm{~mm}$ thick support made of S235 structural steel was used. Successive layers were deposited using G3Sil wire, whose chemical composition is shown in Table 1. To ensure the adhesion of the hard layer and to avoid any flaking phenomena, a nickel alloy buffer layer was deposited prior to depositing by thermal spraying using G3Si1 wire.

The technological parameters used in the thermal spraying process by electric arc metallization plant were: 0.4 - $0.5 \mathrm{MPa}$ compressed air spraying gas, $28 \mathrm{~V}$ electric arc voltage, 200 A current intensity, 1.6 $\mathrm{mm}$ wire diameter, $100-110 \mathrm{~mm}$ spraying distance, $150 \mathrm{~m} / \mathrm{s}$ sprayed particle rate, $90^{\circ}$ spraying angle.

Table 1. The chemical composition of the G3Si1 wire

\begin{tabular}{|c|c|c|c|c|c|c|c|c|c|c|}
\hline \multirow[b]{2}{*}{ Wire } & \multicolumn{9}{|c|}{ Chemical elements, wt.\% } & \\
\hline & $\mathrm{C}$ & $\mathrm{Si}$ & $\mathrm{Mn}$ & $\mathrm{P}$ & $\mathrm{Cu}$ & $\mathrm{Cr}$ & $\mathrm{Ni}$ & Mo & $\mathrm{S}$ & $\mathrm{Al}$ \\
\hline G3Si11 (RYWAL RHC) & 0.08 & 0.82 & 1.51 & 0.011 & 0.21 & 0.11 & 0.12 & 0.10 & 0.012 & - \\
\hline
\end{tabular}

\section{HVOF thermal spraying process}

The substrate material chosen for producing the samples loaded by HVOF spraying was made of 8 mm thick S275 structural steel (Figure 2). Tungsten carbide powder WC/CoCr 86/10-4 was used as filler material, having the chemical composition shown in Table 2.

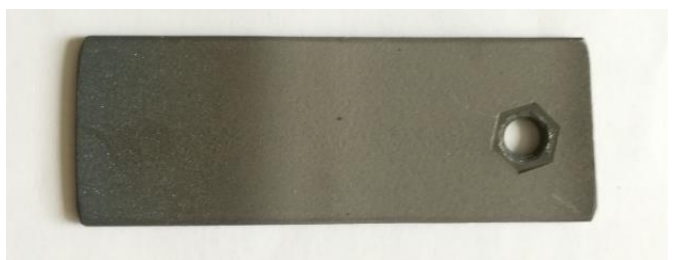

Figure 2. The aspect of the sample loaded by HVOF thermal spraying 
Table 2. The chemical composition of the WC/CoCr 86/10-4 powder

\begin{tabular}{|c|c|c|c|c|c|c|}
\hline \multirow[b]{2}{*}{ Sintered powder } & \multicolumn{6}{|c|}{ Chemical elements, wt.\% } \\
\hline & $\mathrm{W}$ & Co & $\mathrm{Cr}$ & $\mathrm{C}$ & $\mathrm{O}$ & $\mathrm{Fe}$ \\
\hline WC/CoCr 86/10-4 (GTV) & Ballance & 10 & 4 & 5.3 & 0.03 & 0.005 \\
\hline
\end{tabular}

The parameters of the HVOF spraying metallization process were: 7 bar fuel gas (propane) pressure, 10 bar oxygen pressure, 7 bar spraying air pressure, $45 \mathrm{~g} / \mathrm{min}$ powder flow rate, $280 \mathrm{~mm}$ spraying distance, $1600-2000 \mathrm{~m} / \mathrm{s}$ particle spraying rate range, $90^{\circ}$ spraying angle.

\section{Results and discussions \\ Microstructural examination}

The microstructural examination was performed on surfaces sampled from cross sections. The samples were cut using an abrasive wheel and coolant in the IsoMet 4000 precision cutting machine, the wheel being positioned perpendicular to the metallic deposit. For further processing, the samples were embedded in phenolic resin (Figure 3) using the IPA 40 press. The layer that was thermally and mechanically affected by cutting was removed by metallographic grinding on the Buehler automatic machine using abrasive paper (with progressive 360, 600 and 1000 grit). The surfaces were polished using fine alpha alumina abrasive powder of $3.0-0.25 \mu \mathrm{m}$ grain size. The polished surfaces were degreased with ethanol and then dried with hot air jet. There was not applied a chemical attack with metallographic reagent, in order not to affect the chemical composition of the samples subjected to metallographic analysis.

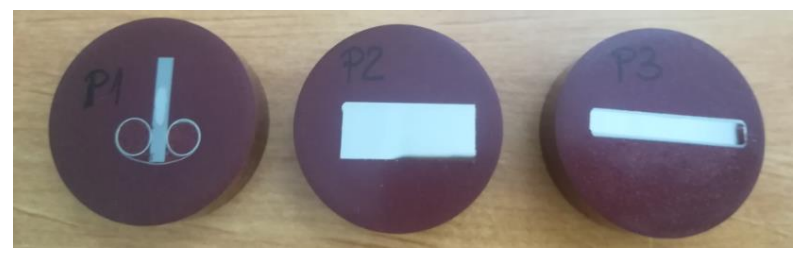

Figure 3. Samples embedded in phenolic resin for metallographic processing P1 chromed specimen; P2 specimen loaded by electric arc and G3Si1 wire; P3 specimen loaded with tungsten carbide

The optical microscopy examination was aimed at the microstructural analysis of the zones adjacent to the layers deposited by metallization and at measuring the thickness of the layers. The metallographic analysis was performed by optical microscopy, according to SR EN 1321:2000, using an Olympus GX51 microscope equipped with the AnalySIS specialized software for image processing. The SEM electron microscopy analysis was performed according to SR EN 1321:2001 using a Quanta Inspect S, FEI Netherlands electron microscope equipped with a Z2e EDAX sensor. The analysed samples were coded (P1, P2, P3) and data on the materials, the thermal spraying processes and the thickness of the layers is presented in Table 3.

Figure 4 shows the cross-section through the layer deposited by hard chromium plating. The deposited layer is even, compact and free of major flaws. The parallel striations along the chromium layer were caused by grinding. There is noted the occurrence of a thermally affected zone at the interface with the support material, extending over approximately $20 \mu \mathrm{m}$.

Table 3. Data on samples subjected to metallographic analysis

\begin{tabular}{|c|c|c|c|c|}
\hline $\begin{array}{c}\text { Sample } \\
\text { code }\end{array}$ & Process for producing hard layers & Layer thickness $[\mu \mathrm{m}]$ & Substrate material & Deposited material \\
\hline P1 & Hard chromium plating & $\sim 18$ & $\begin{array}{c}\text { Heat-resistant steel, } \\
\text { containing about 2\% Cr }\end{array}$ & Chromium with Gadolinium \\
\hline P2 & Electric arc spraying and 2 wires & $\begin{array}{c}100-\text { hard layer } \\
75-\text { adhesion layer }\end{array}$ & Structural steel S 235 & $\begin{array}{c}\text { G3Si1 wire for wear layer and } \\
\text { Ni for adhesion layer }\end{array}$ \\
\hline P3 & $\begin{array}{c}\text { High rate spraying with oxygen- } \\
\text { propane flame (HVOF) }\end{array}$ & $\sim 575$ & Structural steel S 275 & $\begin{array}{c}\text { WC/CoCr86 powder } \\
10-4 \text { participation }\end{array}$ \\
\hline
\end{tabular}




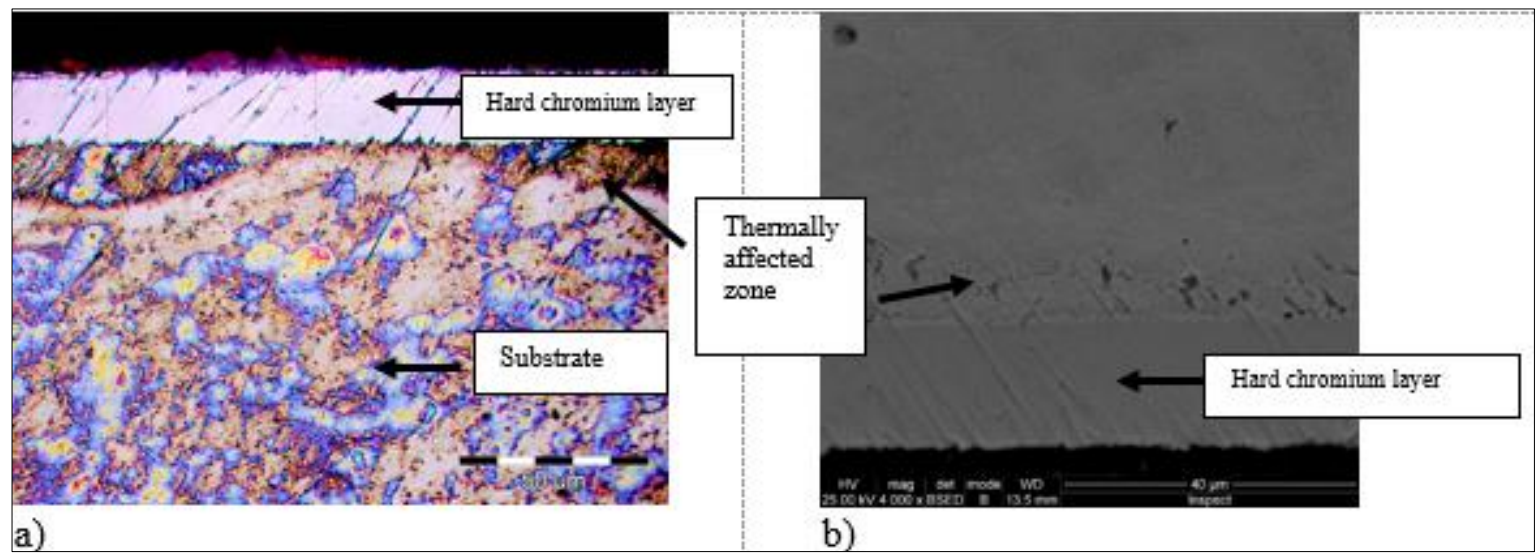

Figure 4. Cross-section of the sample loaded by hard chromium plating (P1).

a) optical microscopy; b) SEM electron microscopy

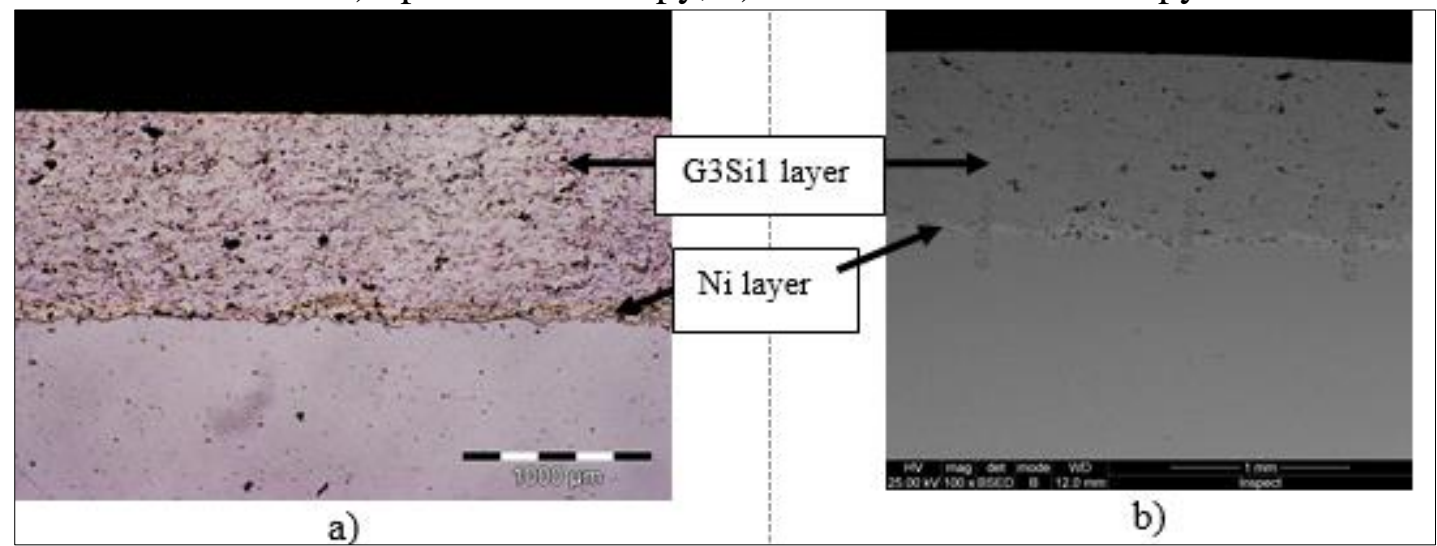

Figure 5. Cross-section of the sample metallicized using an electric arc (P2).

a) Optical microscopy. b) SEM electron microscopy

The metallic layer is even, compact and has small imperfections (isolated pores, inclusions and crusts of oxides). The deposited layer has a quasi-even thickness and the interface with the support material is continuous, free of peeling or other unacceptable flaws. There is noted an intermediate layer of $\mathrm{Ni}$, very thin and uneven, deposited at the interface with the support material.

The cross-section of the layer deposited by thermal spraying with oxy-propane flame and WC/CoCr86 powder is shown in Figure 6. The metallic layer is even, compact and has small imperfections (isolated pores, inclusions and crusts of oxides).

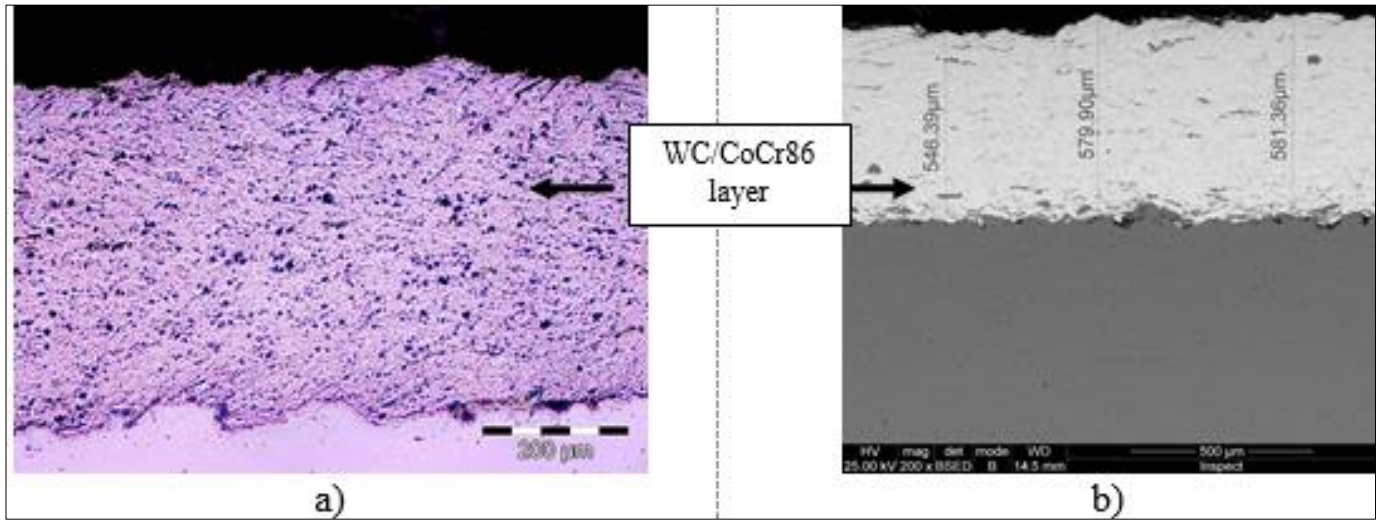

Figure 6. Cross-section of the sample metallized using the HVOF process (P3). a)optical microscopy; b) SEM electron microscopy 
As a result of the high impact energy, small fragments from the surface of the support material flaked off and were embedded in the first metallized layers. Some inclusions of various shapes (elongated or rounded) are present in the upper layers as well (Figure 7).

A flaking zone on the surface of the support material and inclusions of various shapes (dark-coloured) embedded in the material deposited by metallization are highlighted in Figure 7a. At higher magnifications (10000x, Figure $7 b$ ), there can be seen polyhedral grains of light-coloured tungsten carbide (200 $\mathrm{nm}$ and $1.84 \mu \mathrm{m}$ grain size) and the bonding zones between them, consisting of CoCr alloy.

There can also be seen a massive inclusion caused by the flacking of the surface of the support material, dark-coloured.

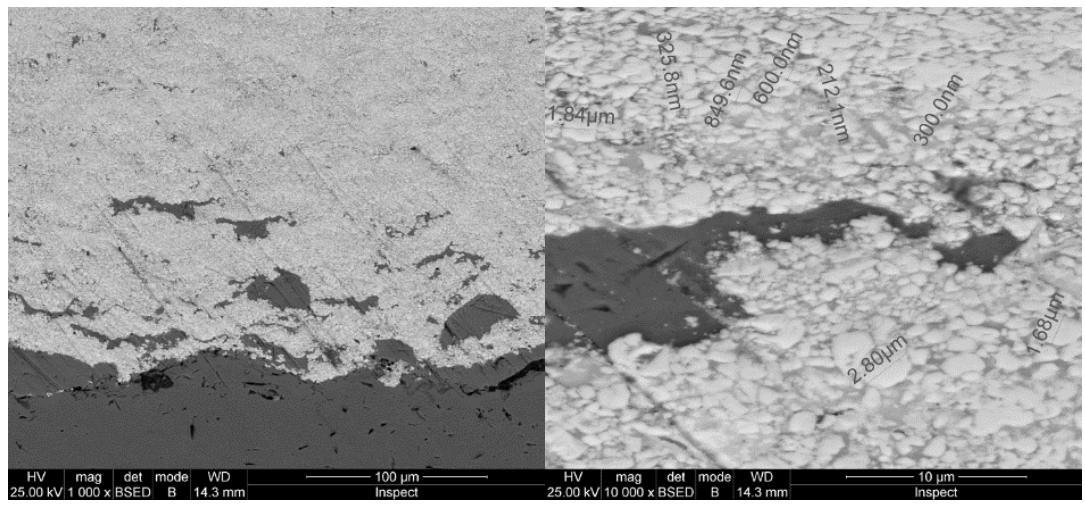

a) b)

Figure 7. Detail on the interface between the layer deposited by HVOF metallization and the steel substrate for sample P3.

\section{Chemical composition analysis}

The local chemical composition was analysed using the EDAX (Energy Dispersive Spectroscopy) method, a Z2e-type energy dispersive X-ray spectrometer fitted to an Inspect S (FEI Netherlands) electron scanning microscope within the UPB's LAMET laboratory. The measurement micro-zones and the determined values of the chemical compositions are shown in Figure 8 (P1), Figure $9(\mathrm{P} 2)$ and Figure $11(\mathrm{P} 3)$.

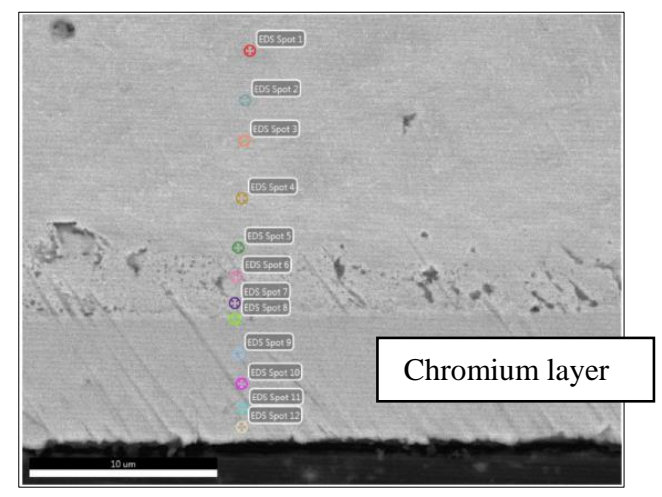

a)

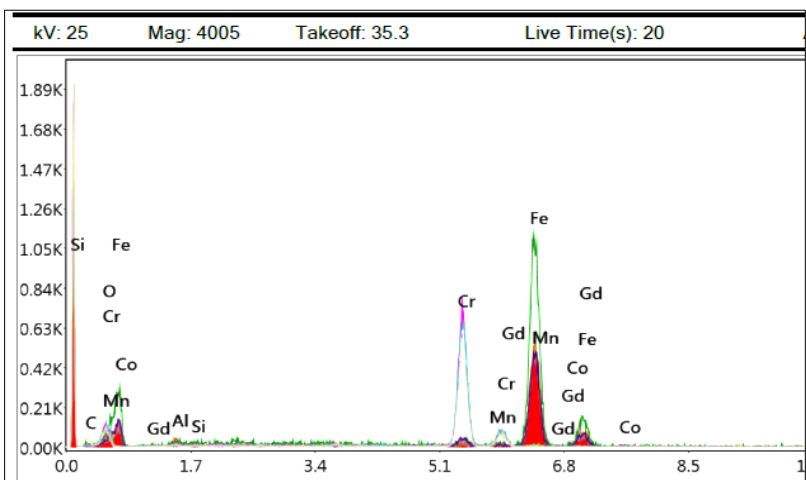

b)

Figure 8. The location of the chemical composition measurement zones on the chromed layer cross-section (a) and the energy dispersive X-ray (EDAX) spectra cumulated for all the measurement points associated with the microzone (b)

The local chemical composition analyses revealed the presence of alloying elements in each zone in Figure 8, as follows: Fe (84.15 - 70.95 wt.\%), Mn (4.7 - 1.18 wt.\%), Si (2.67 - 0.95 wt.\%), Al (6.4 - 5.99 wt.\%), Cr (11.64-2.11 wt.\%), in the support material, noting that higher values of chromium 
concentrations were ascertained on the zones near the interface with the electrochemical deposition (transition zone); Cr (93.66 - 89.88 wt.\%), Co (4.06 - 1.53 wt.\%) and Gd (9.18 - 6.34 wt.\%) on the interface with the steel support; $\mathrm{Cr}(98.25$ - 90.20 w.t\%), O (1.13 - 0.94 wt.\%) and Gd (7.50 - 6.34 wt.\% in electrochemical chromium deposition.

The presence of oxygen in relatively small quantities shows that the deposition was performed in good conditions, as confirmed by the higher wear resistance characteristics of the chromed layer. For the sample with thermal spraying deposition using an electric arc and G3Si1 wire, the chemical composition analyses reconfirmed the presence of the nickel adhesion intermediate layer, where the $\mathrm{Ni}$ concentration ranged from 67.32 to $79.54 \mathrm{wt} . \%$.

The chemical composition of the layer deposited by thermal spraying (Figure 9) was similar to that of the wire used, containing the main alloying elements: Fe $(63.26-42.70 \mathrm{wt} . \%), \mathrm{Si}(1.42-0.83 \mathrm{wt} . \%)$, Mn (2.07 - 1.46 wt.\%), Cr (39.05 - 28.59 wt.\%), Mo (1.42 - 0.47 wt.\%).

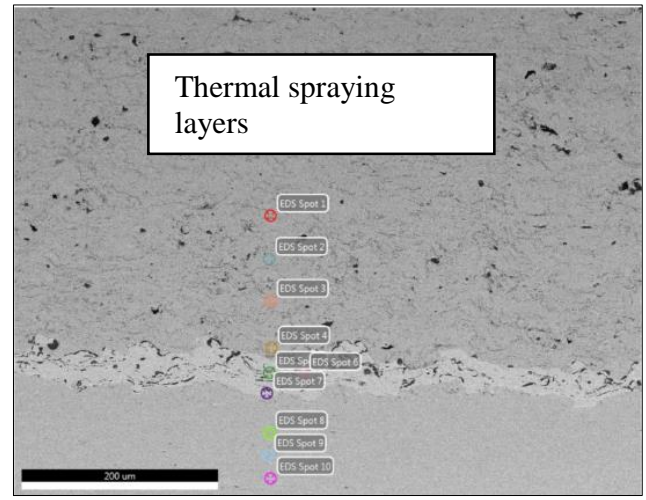

a)

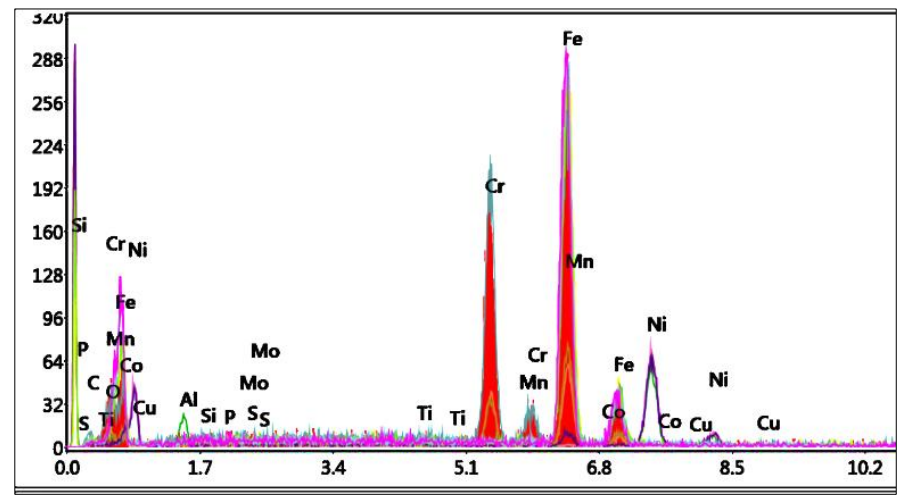

b)

Figure 9. The location of the chemical composition measurement zones on the cross-section of the layer deposited by thermal spraying using an electric arc (a) and the energy dispersive X-ray (EDAX) spectra cumulated for all the measurement points associated with the microzone (b)

The chemical composition analysis on micro-zones for the sample produced by thermal spraying with oxy-propane flame (HVOF) and WC/CoCr86 powder mixture is shown in Figure 10. The chemical composition of the layer deposited by thermal spraying contained the following main alloying elements: Co (24.85 - 7.23 wt.\%), Cr (23.74 - 4.08 wt.\%), W (82.79 - 3.63 wt.\%), C (5.66 - 4.54 wt.\%). In this case as well, the percentage of oxygen is low, the highest measured value being $3.02 \mathrm{wt} \%$ at the interface with the substrate material.

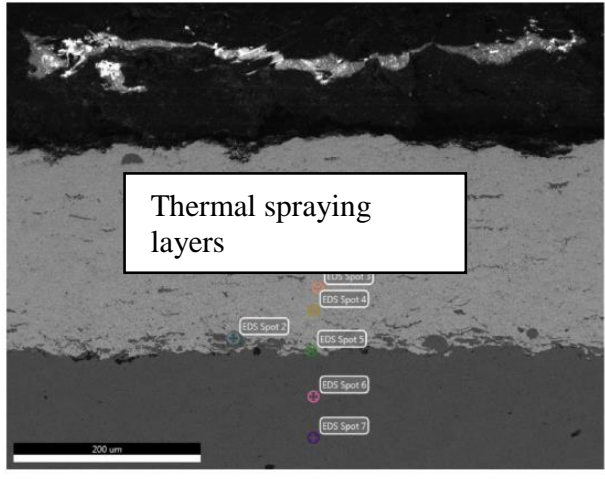

a)

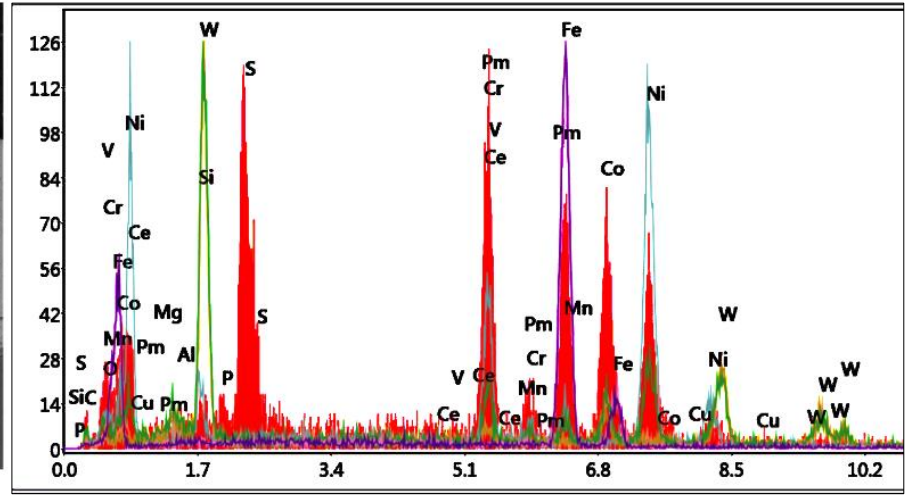

b)

Figure 10. The location of the chemical composition measurement zones on the cross-section of the layer deposited by thermal spraying using an oxy-propane flame (HVOF) (a) and the energy dispersive X-ray (EDAX) spectra cumulated for all the measurement points (b) 


\section{Microhardness measurements}

The microhardness measurements were performed using the Shimadzu HMV 2T microhardness tester within the LAMET laboratory, according to SR EN ISO 6507-1:2006. The measurements were performed in line, with distances between prints of at least $500 \mu \mathrm{m}$. Several measurements were performed on the deposited layers and on the zones bordering the support material, both in cross-section and on the deposited layer, after a prior processing carried out by grinding, at a pressing force of $0.98 \mathrm{~N}$ (HV 0.1) and pressing time of 10 seconds. The evolution of the microhardness values measured on the surface of the deposited layers is shown in Figure 11.

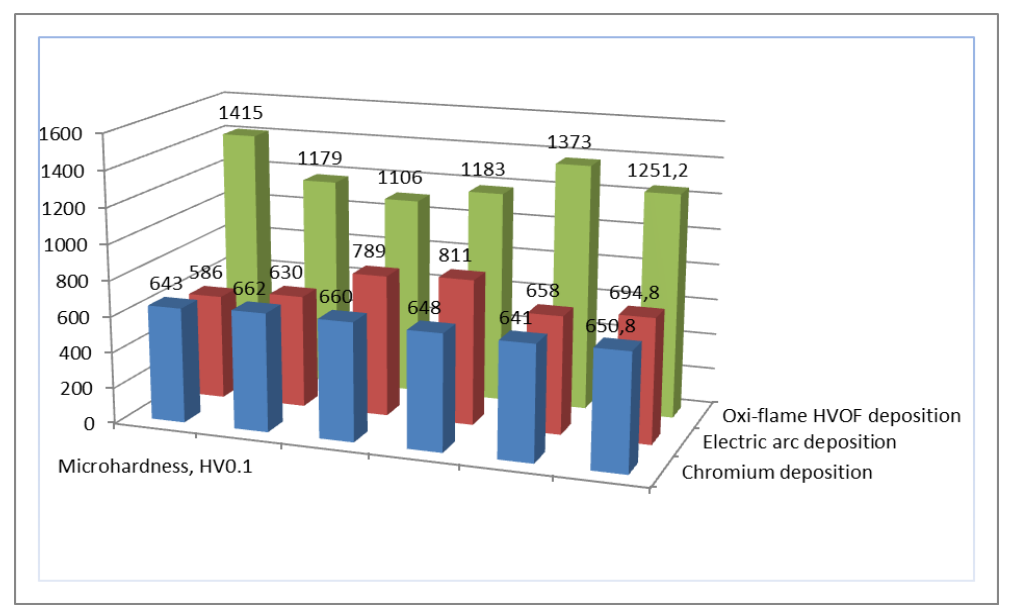

Figure 11. Microhardness values measured on the surface of the deposited metallic layers

The microhardness evolution analysis shows that the highest values were determined at the surface loaded by spraying with $\mathrm{WC} / \mathrm{CoCr} 86\left(1251 \mathrm{HV}_{0.1}\right)$ powder mixture, compared to the values achieved in the other two types of deposits, respectively an average of $650 \mathrm{HV}_{0.1}$ for electrochemical deposition with chromium and $695 \mathrm{HV}_{0.1}$ for loading by spraying with G3Sil wire. The measurements were then performed on the cross-sections of the specimens processed by metallographic procedure and the values are summarized in Tables 4 to 6.

Table 4. Microhardness values determined in cross-section for sample P1

\begin{tabular}{|c|c|c|c|c|}
\hline \multirow{2}{*}{ Individual values } & \multicolumn{3}{|c|}{ P1 } \\
\cline { 2 - 5 } & \multicolumn{2}{|c|}{ Chromium layer } & Transition zone & Substrate material \\
\cline { 2 - 5 } & $\mathbf{H V}_{\mathbf{0 . 0 5}}$ & HRC & $\mathbf{H V}_{\mathbf{0 . 1}}$ & $\mathbf{H V}_{\mathbf{0 . 1}}$ \\
\hline 1 & 595 & 55 & 147 & 154 \\
\hline 2 & 548 & 52.2 & 162 & 155 \\
\hline 3 & 549 & 52.3 & 154 & 149 \\
\hline 4 & 555 & 52.6 & 151 & 167 \\
\hline 5 & 626 & 56.6 & 164 & $\mathbf{1 5 6 . 2}$ \\
\hline Average value & $\mathbf{5 7 5}$ & $\mathbf{5 3 . 7 4}$ & $\mathbf{1 5 6}$ & \\
\hline
\end{tabular}

Table 5. Microhardness values determined in cross-section for sample P2

\begin{tabular}{|c|c|c|c|c|}
\hline \multirow{2}{*}{$\begin{array}{l}\text { Individual } \\
\text { values }\end{array}$} & \multicolumn{4}{|c|}{ P2 } \\
\cline { 2 - 5 } & \multicolumn{2}{|c|}{ Arc spraying layer } & Ni buffer layer & Substrate material \\
\cline { 2 - 5 } & $\mathbf{H V}_{\mathbf{0 . 1}}$ & HRC & $\mathbf{H V}_{\mathbf{0 . 1}}$ & $\mathbf{H V}_{\mathbf{0 . 1}}$ \\
\hline 1 & 894 & 66.8 & 104 & 174 \\
\hline 2 & 665 & 58.6 & 155 & 193 \\
\hline 3 & 654 & 57 & 151 & 178 \\
\hline 4 & 858 & 65.7 & 140 & 183 \\
\hline 5 & 674 & 59 & 156 & $\mathbf{1 7 9 . 8}$ \\
\hline Average value & $\mathbf{7 4 9}$ & $\mathbf{6 1 . 4 2}$ & $\mathbf{1 4 1 . 2}$ & \\
\hline
\end{tabular}


Table 6. Microhardness values determined in cross-section for sample P3

\begin{tabular}{|c|c|c|c|c|}
\hline \multirow{3}{*}{$\begin{array}{l}\text { Individual } \\
\text { values }\end{array}$} & \multicolumn{4}{|c|}{ P3 } \\
\hline & \multicolumn{2}{|c|}{ HVOF layer } & \multirow{2}{*}{$\begin{array}{c}\text { Transition zone } \\
\text { HV }_{0.1} \\
\end{array}$} & \multirow{2}{*}{$\begin{array}{c}\text { Substrate material } \\
\mathbf{H V}_{\mathbf{0 . 1}} \\
\end{array}$} \\
\hline & $H_{V_{0.1}}$ & HRC & & \\
\hline 1 & 1011 & - & 235 & 165 \\
\hline 2 & 911 & 67.2 & 212 & 150 \\
\hline 3 & 995 & 64.8 & 216 & 168 \\
\hline 4 & 1067 & - & 203 & 166 \\
\hline 5 & 910 & 61.4 & 205 & 148 \\
\hline Average value & 978.8 & - & 214 & 159 \\
\hline
\end{tabular}

There is found that the microhardness in cross-sections is lower for the samples loaded electrochemically and using the HVOF process, which shows that the manner of formation of the layers using these methods determined the occurrence of the anisotropy of the hardness characteristics in different directions. In contrast, in the case of deposition by thermal spraying with electric arc, there is found an increase of the average hardness in cross-section, from about $650 \mathrm{HV}_{0.1}$ to $749 \mathrm{HV}_{0.1}$.

\section{Conclusions}

The deposition of composite metallic layers using various methods allows the assessment and selection of their fields of use, according to the mechanical and microstructural characteristics achieved. The comparative analysis of 3 different methods of depositing composite metallic layers allowed highlighting the microstructural particularities thereof.

In the case of electrochemical deposition of the chromium layer, there was found an evenness of the deposition, its good adherence to the base material and the lack of major flaws such as cracks, flaking or pores. Chromium concentration in the layer was over 98 wt.\% ensuring good mechanical characteristics (hardness between 575 and $650 \mathrm{HV}_{0.1}$ ) and high corrosion resistance.

For the sample performed by spraying with electric arc and G3Si1 wire, the microhardness values are slightly higher compared to those obtained by electrochemical deposition method. The productivity of producing the layers is higher, considering the lower cost per unit area and the much shorter processing time, the number and size of the pores are low, ensuring good operating behaviour.

The deposited layer performed by spraying with oxy-propane flame and metallic-ceramic powders (WC/CoCr 86/10-4) contains cobalt (over 25 wt.\%), chromium (over 23 wt.\%) and carbides. The microstructure of the deposited layer highlights the presence of partially melted and flattened particles. There were observed fine and evenly distributed pores as well as the incorporation of particles from the surface of the base material. The deposited layer (average thickness of $550 \mu \mathrm{m}$ ) is even, adherent and relatively compact. There were found no cracks or flaking in the deposited layer.

The microhardness measured on the surface of the layer deposited with WC/CoCr 86/10-4 powders is significantly higher than the microhardness determined on the layers chromed or metallized using an electric arc, the average value being over $1250 \mathrm{HV}$. The formation of oxides during spraying may cause a decrease in hardness, but the oxygen level detected by chemical composition analyses on micro-zones showed relatively low oxygen levels (below $3 \mathrm{wt} \% \mathrm{O}$ ).

\section{References}

1.BUSARU, A. E., GORAN, M., GHETA, R. A., DUMITRU, G. M., IACOBESCU, G., Experimental research on structural hardening of the maximum stressed crankshafts surfaces obtained by thermal spraying”, UPB Sci. Bull, Series D, 79, Issue 4, 2017, p.227-238.

2.BRATEAN, L., MICLOSI, V., VOICULESCU, I., IACOBESCU, G., Research on Anticorrosion Characteristics of AlZn Pseudo-Alloy Obtained by Metal Arc Process, U.P.B. Sci. Bull., Series D, 73, Issue 4, 2011, p. 150-164. 
3.PAVAlACHE, A.C., VASILE, I.M., STANCIU, E.M., VOICULESCU, I., Case Study about the Effect of Measurement Parameters Values on the Microhardness Results, 2009 IEEE International Workshop Advanced Methods for Uncertainty Estimation in Measurement Proceedings, Bucharest, Romania, (2009), p. 54-58.

4.PAVALACHE, A.C., VOICULESCU, I., IORDACHESCU, D., VASILE, I.M., STANCIU, E.M., APOSTOL, G., Obtaining Of Metal Matrix Composites Layers By Laser Cladding, Metalurgia International XVI, Special Issue 5, 2011, p. 121-124.

5.VOICULESCU, I., GEANTA, V., VASILE, I.M., STEFANOIU, R., TONOIU, M., Characterization of weld deposits using as filler metal a high-entropy alloy, Journal of Optoelectronics and Advanced Materials, 15, No. 7-8, 2013, p. 650-654.

6.STANCIU, E. M., PASCU, A., TIEREAN, M. H., VOICULESCU, I., ROATA, I. C., CROITORU, C., HULKA, I., Dual Coating Laser Cladding of NiCrBSi and Inconel 718, Materials and Manufacturing Processes, 31, Issue 12, 2016, p. 1556-1564.

7.PASCU, A., STANCIU, E.M., VOICULESCU, I., TIEREAN, M. H., ROATA, I.C., OCANA, J.L., Chemical and Mechanical Characterization of AISI 304 and AISI 1010 Laser Welding, Materials and Manufacturing Process, 31, Issue 03, 2016, p. 311-318.

8. VOICULESCU, I., GEANTA, V., VASILE, I.M., STEFANOIU, R., IACOB, M., Researches regarding the obtaining of the electrode for spot welding. Metalurgia International, Special Issue 1, 2013, p.52-55.

9. FAUCHAIS, P., VARDELLE, A., Thermal Sprayed Coatings Used Against Corrosion and Corrosive Wear, Advanced plasma spray applications, 2012, p 1-36.

10. VOICULESCU, I., RONTESCU, C., DONDEA, I. L., Metalografia Imbinarilor Sudate (Metallography of Welded Structures), Ed. SUDURA, Timisoara, 2010.

11. NAHMANY, M., HOOPER, Z., STERN, A., GEANTA, V., VOICULESCU, I., AlxCrFeCoNi High-Entropy Alloys: Surface Modification by Electron Beam Bead-on-Plate Melting, Metallography Microstructure and Analysis, 5, Issue 3, 2016, p. 229-240.

12. VOICULESCU, I., GEANTA, V., VASILE, I.M., Aliaje feroase pentru structuri sudate (Ferrous Alloys for Welded Structures) Ed. BREN, Bucuresti, 2016.

13. VOICULESCU, I., GEANTA, V., STEFANOIU, R., BINCHICIU, H., VIDA-SIMITI I., JUMATE, N., VASIU, R., Study on Hardfaced Wear Resistant Bronze Alloy, Friction, Wear and Wear Protection International Symposium, Germany, 2008, p.610- 617.

14. HULKA, I., UTU, D., SERBAN, V.A., DAN, M.L., MATIKAINEN V., VUORISTO, P., Corrosion Behavior of WC-FeCrAl Coatings Deposited by HVOF and HVAF Thermal Spraying Methods, Chemical Bulletin of "Politehnica" University of Timisoara, Romania, Series of Chemistry and Environmental Engineering, 61, (75), 1, 2016, p1-6.

15. GEANTA, V., VOICUlESCU, I., MILOSAN, I., ISTRATE, B., MATES, I. M., Chemical Composition Influence on Microhardness, Microstructure and Phases Morphology of $\mathrm{Al}_{x} \mathrm{CrFeCoNi}$ High Entropy Alloys, Rev. Chim., 69, (4), 2018, 798

16. GARLEANU, D., GARLEANU, G., Effect of Chemical Composition on Hard Deposits Properties in the Case of Weld Refurbishment of Heavy Crushing Hammers, Rev. Chim., 70 (2), 2019, 417

17. VOICULESCU, I., GEANTA, V., STEFANOIU, R., PATROI, D., BINCHICIU, H., Influence of the Chemical Composition on the Microstructure and Microhardness of AlCrFeCoNi High Entropy Alloy, Rev. Chim., 64, (12), 2013, 1441

18. ROLLER, J., Reactive Spray Deposition, Syringe pump application note AN 9, University of British Columbia, USA, 2012.

19. AMIN, S., PANCHAL, H., A Review on Thermal Spray Coationg Process, International Journal of Current Trends in Engineering \& Research (IJCTER), 2, Issue 4, 2016, p.556 - 563. 
20. MOHAMED, D., EDDINE, B.N., NACER, D., Effect of Substrate Preheating, Roughness and Particles Size on Splat Morphology of Thermal Sprayed Coatings, International Journal of Computational and Experimental Science and Engineering (IJCESEN) 1, No.1 2015, p. 16-18.

21. MATEJICEK, J., VILEMOVA, M., MUSALEK, R., SACHR, P., HOMIK, J., The Influence of Interface Characteristics on the Adhesion/Cohesion of Plasma Sprayed Tungsten Coatings, Coatings, 3, 2013, p.108-125.

22. WANG, Y.Y., LI, C.J., OHMORI, A., Influence of substrate roughness on the bonding mechanisms of high velocity oxy-fuel sprayed coatings, Thin Solid Films 485, 2005, p. 141 - 147.

23. KURODA, S., KAWAKITA, J., FUKUSHIMA, T., TOBE, S., Importance of the Adhesion of HVOF Sprayed Coatings for Aqueous Corrosion Resistance, Materials Transactions, 44, No. 3, 2003, p. 381388.

24. YAMAZAKI, Y., ARAI, M., MIYASHITA, Y., WAKI, H., SUZUKI, M., Determination of Interfacial Fracture Toughness of Thermal Spray Coatings by Indentation, JTTEE 5, 22, Issue 8, 2013, p.1358-1365.

Manuscript received:24.10.2019 